Science Archives (2020) Vol. 1 (1), 35-41

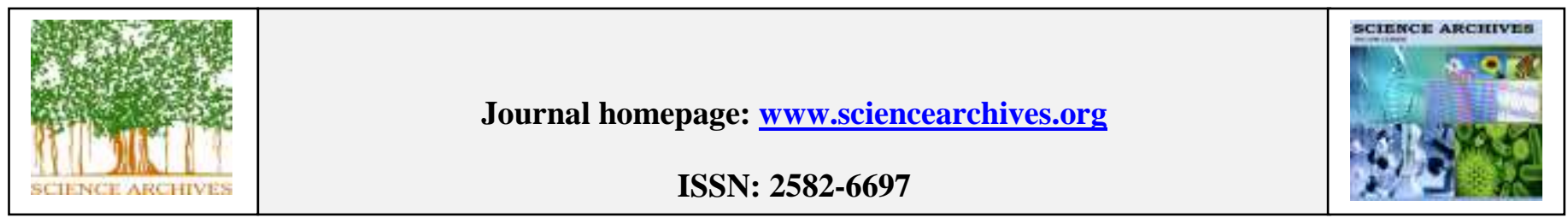

Review Article

http://dx.doi.org/10.47587/SA.2020.1104

\title{
Cyanobacteria: an emerging source for antibacterial, antimycobacterial and antifungal properties
}

\author{
Abhishek Chauhan ${ }^{1 \ltimes<}$, Ritu Chauhan ${ }^{1}$, Rupesh Kumar Basniwal ${ }^{2}$ and Sachin C. Narwadiya ${ }^{3}$ \\ ${ }^{1}$ Amity Institute of Environmental Toxicology, Safety and Management, Amity University, Sector-125, \\ Noida, Uttar Pradesh, India \\ ${ }^{2}$ Amity Institute for Advanced Research and Studies (M\&D) Amity University, Sector-125, \\ Noida, Uttar Pradesh, India \\ ${ }^{3}$ Vigyan Prasar, Department of Science and Technology, Govt. of India, C-24, Qutub Institutional Area, New Delhi-110016 \\ D.< akchauhan@amity.edu \\ Received Date: Feb 17, 2020 / Accepted Date: June 23, 2020 / Published Date: June 28, 2020
}

\begin{abstract}
Cyanobacteria are various group of gram-negative prokaryotes that originated before 3.5 billion years ago known as phototrophic blue green algae. This group is well known for their higher photosynthetic growth rate and capability to grow in adverse environmental conditions. Unique property of the algal group to grow in almost every environmental condition, makes them suitable candidate for the study of antimicrobial research. First time before $1500 \mathrm{BC}$, medicinal and nutritional properties have been investigated for Nostoc algal species to treat gout, fistula and cancer. In current scenario, less accessibility of life saving drugs, high cost of antibiotics and development of resistivity towards existing antibiotics, made it necessary to look forward for new research activities based on cyanobacteria and other plants for betterment of human society. The different extracts prepared from cultured cyanobacteria to isolate compounds are a common way to discover novel compounds. Most of the valuable cyanobacterial metabolites are concentrated in their biomass. For existence in nature, cyanobacteria secrete and contain various organic compounds. Compounds like proteins, fatty acids, vitamins, pigments, primary and secondary metabolites extracted from cyanobacteria are well known for different antimicrobial activities like antifungal, antiviral and antibacterial. Pharmaceutical companies have been shown commercial interest in this algal group due to presence of vast and diverse biological active compounds. In this review, we have shown panoramic view of cyanobacterial extracts and their commercial applications in different fields.
\end{abstract}

Keywords: Antibacterial, antimycobacterial and antifungal properties, cyanobacteria

\section{Introduction}

Cyanobacteria are the oxygenic, photosynthetic, gramnegative, oldest phototrophic organisms exhibited diverse biological activities. Approximately 2000 different strains of freshwater and marine cyanobacteria are found throughout world, which shows extraordinary ecological variety. Capability to grow in adverse condition and their autotrophic nature makes them eligible candidate to grow in low nutrient deficient lakes, ponds and oceans which pose serious threat for water and result into eutrophication (Chorus and Bartram, 1999; Duy et al., 2000). They are well known for different antimicrobial activity and being used for production of various value-added products throughout the world. The first partly identified antimicrobial compound isolated from algae were obtained from unicellular green algae particularly, Chlorella which contained a substance termed as 'chlorellin' that exhibited inhibitory activity against Gram-positive and Gram-negative group of bacteria. In pharmaceutical companies especially in new drug discovery research division, last 40 years research is going on extraction of new compounds or drugs from cyanobacteria. Their development without supplement of organic substrate can be a practical advantage over the 


\section{Science Archives (2020) Vol. 1 (1), 35-41}

Table 1: Antibacterial, antimycobacterial and antifungal properties of Cyanobacteria (from 1962 to 2019)

\begin{tabular}{|c|c|c|}
\hline Cyanobacteria & Bacterial and Fungal species & References \\
\hline Lyngbya majuscule & $\begin{array}{l}\text { Bacillus subtilis, Bacillus subtilis, Bacillus typhosus, } \\
\text { Mycobacterium balnei, } \\
\text { Mycobacterium smegmatis, Sarcina lutea, Staphylococcus } \\
\text { aureus, Candida albicans, Cryptococcus neoformans, } \\
\text { Penicillum sp. }\end{array}$ & $\begin{array}{l}\text { Welch (1962); Gupta and } \\
\text { Shrivastava (1965); Moikeha } \\
\text { and Chu (1971) }\end{array}$ \\
\hline Oscillatoria princes & $\begin{array}{l}\text { Escherichia coli, Staphylococcus aureus, Bacillus subtilis, } \\
\text { Bacillus typhosus, E. coli }\end{array}$ & Gupta and Srivastava, 1965 \\
\hline $\begin{array}{l}\text { Brachytrichia balani, } \\
\text { Mastigocoleus testarum }\end{array}$ & $\begin{array}{l}\text { Salmonella sp., Staphylococcus aureus, Escherchia coli, } \\
\text { Mycobacterium phlei, }\end{array}$ & Kobbia and Zaki, 1976 \\
\hline Lyngbya majuscule & $\begin{array}{l}\text { Mycobacterium smegmatis, Streptococcus pyogenes, } \\
\text { Compound identified: Malyngolide }\end{array}$ & Cardllina and Moore, 1979 \\
\hline $\begin{array}{lrr}\text { Oscillatoria } & \text { sp. } & 1459 / 8, \\
\text { Oscillatoria } & & \text { redekei, } \\
\text { Schizothrix } & \text { sp. } & 1470 / 2, \\
\text { Synechococcus } & \text { leopoliensis, } \\
\text { Schizothrix } & \text { sp. } 1470 / 2, \\
\text { Synechococcus } & \text { leopoliensis, } \\
\text { Fisscherella } & \text { ambigua, } \\
\text { Hapalosiphon hibernicus }\end{array}$ & $\begin{array}{l}\text { Bacillus subtilis, Staphylococcus aureus, Aspergillus } \\
\text { oryzae, Candida albicans, Penicillium notatum, } \\
\text { Saccharomyces cerevisiae, Trichophyton mentagrophytes. } \\
\text { Compound identified: Ambiguines }\end{array}$ & Cannell et al., 1988 \\
\hline Nostoc muscorum & $\begin{array}{l}\text { Staphylococcus aureus, Pseudomonas aeruginosa } \\
\text { Candida albicans, Cunninghamella blakesleeana, } \\
\text { Rhizoctonia solani, Sclerrotinia sclerotiorum }\end{array}$ & $\begin{array}{l}\text { De Cano et al. (1990), } \\
\text { Bloor and England (1989) }\end{array}$ \\
\hline Scytonema sp. & $\begin{array}{l}\text { S. cerevisiae. C.albicans A. oryzae, P. notatum, } \\
\text { Compound identified: Tolytoxin and 6-Hydroxy-7-O- } \\
\text { Mehtylescytophycine }\end{array}$ & Carmeli et al., 1990 \\
\hline Tolyhothrix tjipanensis & $\begin{array}{l}\text { Aspergillus oryzae, Candida albicans, Trichophyton } \\
\text { mentagrophytes }\end{array}$ & Bonjouklian et al., 1991 \\
\hline Westiellopsis prolifica & $\begin{array}{l}\text { C. albicans A. oryzae, Saccharomyces cerevisiae, } \\
\text { Trichophyton mentagrophytes. Penicillium notatum } \\
\text { Compound identified: Ambiguines }\end{array}$ & Smitka et al, 1992 \\
\hline Fischerella ambigua $108 a$ & $\begin{array}{l}\text { Bacillus subtilis, Micrococcus luteus, Escherichia coli. } \\
\text { Compound identified: Ambigol A \& B }\end{array}$ & Falch et al., $1993 \& 1995$ \\
\hline Phormedium sp. HS-273 & Staphylococcus aureus & Ohta et al., 1993 \\
\hline $\begin{array}{l}\text { Phormidium sp., } \\
\text { Mastigocladus laminosus, } \\
\text { Mastigocladus laminosus }\end{array}$ & $\begin{array}{l}\text { Staphylococcus aureus, Bacillus cereus, B. coagulans, B. } \\
\text { licheniformis, B. sphaericus, B. subtilis, Streptococcus } \\
\text { faecalis, S. viridi, E. coli, Proteus vulgaris, P. morganii, } \\
\text { Pseudomonas denitrificans, Candida albicans }\end{array}$ & Fish and Codd, 1994 \\
\hline $\begin{array}{l}\text { Scytonema lyngbyoides, } \\
\text { Anabaena planctonica } 115 \mathrm{~b}, \\
\text { Pseudoanabaena catenata } U 7, \\
\text { Nostoc sp. } 51, \text { Nostoc } \\
\text { commune NC1, Oscillatoria } \\
\text { rubescens } R 19\end{array}$ & $\begin{array}{l}\text { Bacillus subtilis, Micrococcus luteus, Escherichia coli, } \\
\text { Penicillium oxalicum }\end{array}$ & Falch et al., 1995 \\
\hline
\end{tabular}




\section{Science Archives (2020) Vol. 1 (1), 35-41}

\begin{tabular}{|c|c|c|}
\hline $\begin{array}{l}\text { Aphanizomenon flos-aquae, } \\
\text { Anabaena lemmermannii, } \\
\text { Microcystis aeruginosa }\end{array}$ & Bacillus subtilis, Bacillus cereus, Escherichia coli & Stensvik et al., 1998 \\
\hline Nostoc commune & $\begin{array}{l}\text { Aspergillus candidus Compound identified: } \\
\text { Nostofungicidine }\end{array}$ & Kajiyama et al., 1998 \\
\hline Nostoc muscorum 1453/12a & Bacillus subtilis & Cannell et al., 1988 \\
\hline Tychonema bourrellyi & Bacillus subtilis, Bacillus cereus, Escherichia coli & Stensvik et al., 1998 \\
\hline Oscillatoria rubescens & $\begin{array}{l}\text { Staphylococcus aureus, Bacillus subtilis, Micrococcus } \\
\text { flavus }\end{array}$ & Kreitlow et al., 1999 \\
\hline Nostoc commune 259 & Staphylococcus epidermidis & Jaki et al., 1999 \\
\hline Limnothrix sp. & $\begin{array}{l}\text { Staphylococcus aureus, Bacillus subtilis, Micrococcus } \\
\text { flavus. }\end{array}$ & Kreitlow et al., 1999 \\
\hline Fischerella ambigua $108 b$ & $\begin{array}{l}\text { Bacillus cereus, Staphylococcus epidermidis, } \\
\text { Pseudomonas aeruginosa, Escherichia coli, Micrococcus } \\
\text { luteus. }\end{array}$ & Jaki et al., 1999 \\
\hline Anabaena sp., A. solitaria & Micrococcus flavus and Bacillus subtilis & Kreitlow et al., 1999 \\
\hline Lyngbya majuscule & Candida albicans. Compound identified: Tanikolide & Singh et al., 1999 \\
\hline Lyngbya majuscule & Candida albicans compound identified: Tanikolide & Singh et al., 1999 \\
\hline $\begin{array}{l}\text { Langbya sp. 91/50, Langbya } \\
\text { sp. 163, Langbya sp. } 164,\end{array}$ & $\begin{array}{l}\text { Bacillus cereus, Eschrichia coli, Staphylococcus } \\
\text { epidermidis }\end{array}$ & Jaki et al., 1999 \\
\hline Limnothrix sp. & $\begin{array}{l}\text { Staphylococcus aureus, Bacillus subtilis, Micrococcus } \\
\text { flavus. }\end{array}$ & Kreitlow et al., 1999 \\
\hline $\begin{array}{l}\text { Langbya sp. 91/50, Langbya } \\
\text { sp. 163, Langbya sp. } 164, \\
\text { Nostoc commune 122b, Nostoc } \\
\text { commune 123b, Nostoc } \\
\text { commune 124b, Tolypothrix } \\
\text { distorta 153a, Tolypothrix } \\
\text { distorta } 96 \text { c, Scytonema } \\
\text { myochrous 200b, Symploca } \\
\text { muscorum 176, Tolypothrix } \\
\text { byssoidea 195, Phormidium } \\
\text { sp. } 178, \text { Phormidium sp. } 211\end{array}$ & $\begin{array}{l}\text { Bacillus cereus, Staphylococcus epidermidis, Candida } \\
\text { albicans }\end{array}$ & Jaki et al., 1999 \\
\hline Anabaena variabilis 1 & Bacillus subtilis, Chaetomium globosuim, & $\begin{array}{l}\text { Mundt et al., 2001; Kellam et } \\
\text { al., } 1988\end{array}$ \\
\hline $\begin{array}{l}\text { Gloeocapsa caldariorum } 127, \\
\text { Calothrix gracilis } 96, \\
\text { Limnothrix redekei HUB } 052 \\
\text { Limnothrix redekei HUB } 052 \text {, } \\
\text { Nostoc species } 104, \\
\text { Oscillatoria species } 234, \\
\text { Pseudoanabaena catenata }\end{array}$ & Bacillus subtilis & Mundt et al., 2001 \\
\hline $\begin{array}{l}\text { Tolypothrix byssoidea } \\
\text { (EAWAG195) }\end{array}$ & $\begin{array}{l}\text { Candida albicans. Compound identified: Tolybyssidin A } \\
\text { (1) Tolybyssidin B (2) }\end{array}$ & Jaki et al., 2001 \\
\hline
\end{tabular}




\section{Science Archives (2020) Vol. 1 (1), 35-41}

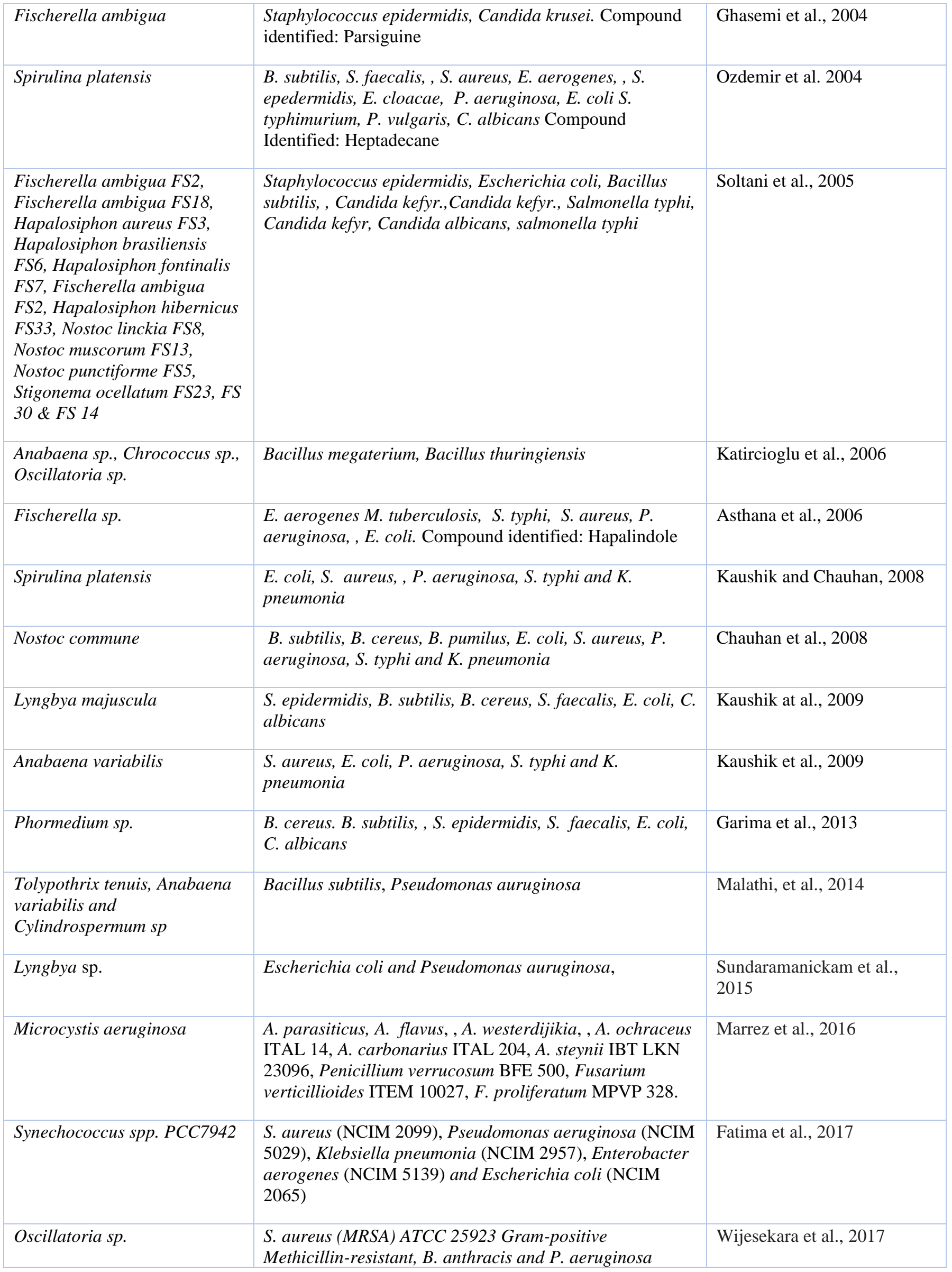


Science Archives (2020) Vol. 1 (1), 35-41

\begin{tabular}{|l|l|l|}
\hline & $\begin{array}{l}\text { (ATCC 25853) E. coli and S. typhi (ATCC 25922 and C. } \\
\text { tropicalis }\end{array}$ & \\
\hline Nostoc linckia & $\begin{array}{l}\text { Pseudomonas aeruginosa Bacillus subtilis, and } \\
\text { Staphylococcus aureus susp. aureus, and two tested fungal } \\
\text { strains Aspergillus niger and Candida albicans }\end{array}$ & Vanlalveni et al., 2018 \\
\hline $\begin{array}{l}\text { Anabaena circinalis, Nostoc } \\
\text { entophytum }\end{array}$ & $\begin{array}{l}\text { Staphylococcus aureus ATCC 25923, E. coli O 157:H7, } \\
\text { L. monocytogenes, Bacillus subtilis ATCC 6633, } \\
\text { Pseudomonas aeruginosa ATCC 27853, Salmonella } \\
\text { typhimurium CCM 5445 }\end{array}$ & Yücer et al., 2018 \\
\hline 35 cyanobacterial extracts & $\begin{array}{l}\text { Bacillus subtilis, Staphylococcus aureus, Streptococcus } \\
\text { sanguinis, Pseudomonas aeruginosa, Escherichia coli, } \\
\text { Candida friedricki, Fusarium oxysporum, Aspergillus } \\
\text { fumigatus, Monographella cucumerina, Alternaria } \\
\text { alternate }\end{array}$ & Saurav et al., 2019 \\
\hline
\end{tabular}

microorganisms. The benefit of microbes, which can be cultured, such as cyanobacteria, is that a sustainable amount of anticipated bioactive compounds can be attained, which is not always possible for a product derived from a microbe other than cyanobacteria. Blue Green algae promise greater opportunities with all relatively inexpensive and easier approaches against some expensive and technically complex methods presently in use for new drug discovery.

\section{Antimicrobial potential of cyanobacteria}

Culturable microorganisms for screening of novel pharmaceuticals are of paramount importance. Historically, actinomycetes have been the most prolific producers of metabolites with significant antimicrobial activities. According to Bradner, actinomycetes are most closely examined group of organisms and presently known for production of more than $95 \%$ antimicrobial compounds in primary screening (Bradner, 1980). They can be cultured in the laboratory with relative ease to provide a consistent source of biologically active secondary metabolites (Patterson et al., 1993). Screening of cyanobacteria for antimicrobial compounds with pharmaceutical value received more attention. The molecules isolated from several cyanobacteria have broad spectrum of potential including fungicides and algicides toxins, antibiotics (Browitzka, 1995) (Table 1). Random screening of cyanobacteria will continue play an important role in the drug discovery process for unforeseeable future.

\section{Cyanobacteria as a source of antifungal compounds}

Flavanoid type compounds, Fischerellin A, Phytoalexin, Tolytoxin, Laxaphycins, Ambiguines, Calophycin, Sctophytin and Laxaphycins have been isolated from Oscillatoria, Scytonema pseudohofmanii, and Anabaena laxa and from other cyanobacterial species also which supposed to have anticandidal and antibacterial activity (Frankmolle et al., 1992). (Table 1)

\section{Cyanobacteria as a source of antibacterial compounds}

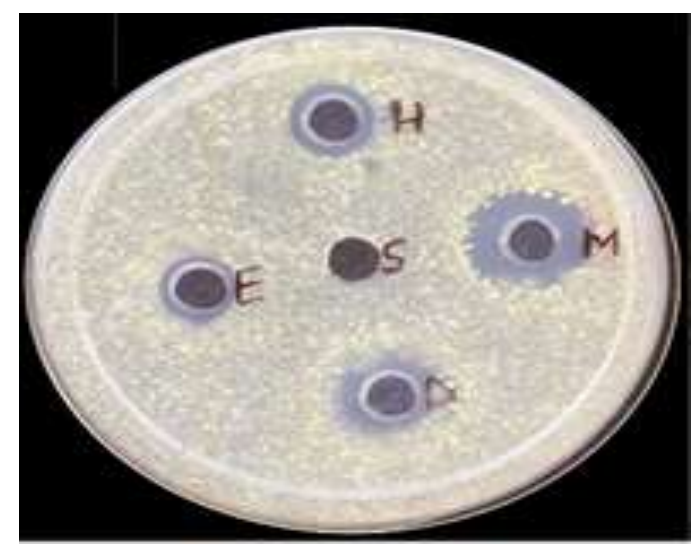

Fig.1. Inhibition zone showed by different extracts of Cyanobacteria against Staphylococcus aureus

Kaushik and Chauhan (2008) have been reported the antibacterial activity of several species of cyanobacteria such as Anabaena, Lyngbya, Calothrix, Spirulina, Nostoc, Hapalosiphone, Phormidium and Oscillatoria etc. against both Gram-positive (S. aureus, B. subtilis, B. cereus etc.) as well as Gram-negative bacteria (E. coli, $P$. aeruginosa, $S$. typhi etc.). These organisms can be genetically modified by using different biotechnological techniques to produce biological active compounds like Bacteriocin, Ambigol A, Parsiguine, Hapalindole, Hormothamnin A etc. Garima et al. (2013) have evaluated Phormidium for its significant antibacterial and anticandidal activity. Various species of Anabaena were evaluated for their antimicrobial activity and for active extracts which further screened for presence of chemical constituents through HPTLC and UV-HPLC techniques (Kaushik et al., 2009a; Chauhan et al., 2010). They have been also examined Nostoc commune and Lyngbya majuscula for potent antimicrobial activity against clinically significant microorganisms and further analyzed 
Science Archives (2020) Vol. 1 (1), 35-41

their methanolic extract through UV-HPLC and HPTLC analysis. (Table 1)

\section{Cyanobacteria as a source of antimycobacterial compounds}

This have been reported by Rao et al. in 2007 for different spp. of cyanobacteria viz. Hapalosiphon sp., Anabaena sp. Lyngbya sp., Westeillopsis prolifica, Spirulina sp. Anabaena variabiles, Anabaena cylindrica, Oscillatoria sp. and Scytonema sp. against various species of Mycobacteria (Mycobacterium tuberculosis ATCC 27294, M.tuberculosis MDR, M.avium, M. intracellulare and M. aurum. (Table 1)

\section{Conclusion and future prospects}

Cyanobacteria produce plenty potential antimicrobial agents which are useful for human as well as for animals' welfare. Worldwide attention is drawn towards micro-algae for their possible use in several therapeutic and other products. Keeping in view the applied applications, it has been concluded that now this area is exploring rapidly. The major challenge in front of the current world is to fight effectively against the new emerging diseases especially multiple drug resistant microbial infections and to discover new compounds for the welfare of mankind and society. Now mostly antibiotics are becoming useless due to development of multiple drug resistivities in pathogens. This is an alarming situation for human species. To overcome from this situation, continuous research in basic as well as applied filed necessary for discovery of new active drug compounds from cyanobacteria.

\section{Conflict of Interest}

Authors hereby declare no conflict of interest.

\section{References}

Asthana, R.K., Srivastava, A., Singh, A.P., Deepali, Singh, S.P., Nath, G., Srivastava, R. and Srivastava, B.S. 2006. Identification of an antimicrobial entity from the cyanobacterium Fischerella sp. isolated from bark of Azadirachta indica (Neem) tree. Journal of Applied Phycology. 18, Number-1, 33-39.

Bloor, S. and England, R.R.1989. Antibiotic production by the cyanobacterium Nostoc muscorum. Journal of Applied Phycology. 1, 367-372.

Bonjouklian, R, Smitka, T.A., Doolin, L.E., Molloy, R.M., Debono, M., Shaffer, S.A., Moore, R.E., Stewart, J.B. and Patterson, G.M.L. 1991 Tjipanazoles, new antifungal agent from the blue green alga Tolypothrix tjipanasensis. Tetrahedron. 47, 7739-7750.

Cannell, R.J.P., Owsianka, A.M. and Walker, J.M. 1988. Results of a Large-Scale Screening Programme to Detect Antibacterial Activity from Freshwater Algae. Br. Phycol. J. 23, 41-44.

Cardellina, J.H., Moore, R.E., Arnold, E.V. and Clardy, J. 1979. Structure and absolute configuration of malyngolide, an antibiotic from the marine blue green alga Lyngbya majuscula Gomont. J. Org. Chem. 44, No-23, 4039-4042.
Carmeli, S., Moore, R.E., and Patterson, G.M.L., Corbett, T.H., and Valeriote, F.A. 1990 c.Tantazoles, unusual cytotoxic alkaloids from the blue-green alga Scytonema mirabile. J. Am. Chem. Soc. 112, 8195-8197.

Carmeli, S., Moore, R.E.and Patterson, G.M.L. 1990 a. Isonitriles from the blue-green alga Scytonema mirabile. J. Org.. Chem. 4431-8.

Carmeli, S., Moore, R.E.and Patterson, G.M.L. 1990 b. Tolytoxin and New Scytophycins from three species of Scytonema. J. Nat. Prod. 53, No-6, 1533-1542.

Chorus, I. and Bartram, J. 1999. Toxic cyanobacteria in the water. E \& F.N. Spon, London.

De Cano, M.M.S., De Mule, M.Cr., De Caire, G.Z., and De Halperin, D.R. 1990. Inhibition of Candida albicans and Staphylococus aureus by phenolic compounds from terrestrial cyanobacterium Nostoc muscorum. Journal of Applied Phycology. 2, No-1, 79-81.

Duy, T.N., Lam, P.K., Shaw, G.R. and Connell, D.W. 2000. Toxicological and risk assessment of freshwater cyanobacterial (blue-green algae) toxin in water. Rev. Environ. Contam. Toxicol. 163, 113-185.

Falch, B.S., Konig, G.M., Wright, A.D. and Sticher, O. 1993. Anbigol A and B: New Biologically Active polychlorinated Aromatic Compounds from the Terrestrial Blue-Green Alga Fischerella ambigua. J. Org. chem. 58, 6570-6575.

Falch, B.S., Konig, G.M., Wright, A.D., Sticher, Angerhofer, C.K., Pezzuto, J.M. and Bachmann, H. 1995. Biological Activities of Cyanobacteria: Evaluation of Extracts and Pure Compounds. Planta Med. 61, 321-328.

Fatima, N., Ahmad, I. Z., \& Chaudhry, H. (2017). Alterations in the antibacterial potential of Synechococcus spp. PCC7942 under the influence of UV-B radiations on skin pathogens. Saudi journal of biological sciences, 24(7), 1657-1662.

Fish, S.A. and Codd, G.A. 1994. Bioactive compound production by thermophilic and thermotolerant cyanobacteria (bluegreen algae). World J. Microbiol. Biotech. 10, 338-341.

Garima, Chauhan, A., Goyal, P., and Kaushik, P (2013) Antibacterial and anticandidal screening of extracellular and intracellular extracts of Phormedium, a cyanobacterium. Int. J. Chem. And Life Sciences, Vol. 2(3), 1107-1111.

Ghasemi, Y., Yazdi, M.T., Shafiee, A., Amini, M., Shokravi, S. and Zarrini, G. 2004. Parsiguine, A Novel Antimicrobial substance from Fischerella ambigua. Pharmceutical Biology. 42, No-5, 318-322.

Gupta, A.B. and Shrivastava, G.C. 1965. On Antibiotic properties of some fresh water algae. Hydrobiologica. 25, 285-288.

Hunter, P.R. 1995. Cyanobacterial toxins and their potential risk to drinking water supplies. Microbiol. Eur. 3, 8-10.

Jaki, B., Orjala, J., Burgi, H.R. and Sticher, O. 1999. Biological Screening of Cyanobacteria for Antimicrobial and Molluscicidal Activity, Brine Shrimp Lethality, and Cytotoxicity. Phrmaceutical Biology. 37, No. 2. 138-143.

Jaki, B., Zerbe, O., Heilmann, J. and Sticher, O. 2001. Two Novel Cyclic Peptides with Antifungal Activity from the Cyanobacterium Tolypothrix byssoidea (EAWAG 195). J. Nat. Prod. 64, 154-158. 


\section{Science Archives (2020) Vol. 1 (1), 35-41}

Jones, G.J. and Korth, W. 1995. In situ production of volatile odor compounds by river and reservoir phytoplankton population in Australia. Water Sci. Technol. 31, 145-151.

Katircioglu, H., Beyatli, Y., Aslim, B., Yuksekdag, Z. and Atici, T. 2006. Screening of antimicrobial Agent Production of Some Microalgae in Freshwater. The internet Journal of Microbiology. 2, No.-2, 1-9.

Kaushik, P. 2000. Introductory Microbiology. Emkay Publications, Post Box 9410, B-19 East Krishna Nagar, Swami Dayanand Marg, Delhi. pp VIII+1-46.

Kaushik, P. and Chauhan, A (2008) Antibacterial potential of aqueous and organic extracts of $\mathrm{N}$. commune a cyanobacterium. VEGETOS (An International Journal of Plant Sciences). Vol. 21, N0.1.77-80.

Kaushik, P. and Chauhan, A (2008) In vitro antibacterial activity of laboratory grown culture of Spirulina platensis. Indian Journal of Microbiology. Vol. 48. No. 3, 348-352.

Kaushik, P., Chauhan, A., Garima, and Goyal P (2009) Antibacterial Potential and UV-HPLC Analysis of Laboratory-Grown Culture of Anabaena variabilis. Internet Journal of Food Safety, Vol.11, 2009, p. 11-18.

Kaushik, P., Garima, Chauhan, A., and Goyal P (2009) Screening of Lyngbya majuscula for potential antimicrobial activity and HPTLC analysis of active methanolic extract. Journal of Pure and Applied Microbiology, Vol.3, No. 1, 169-174.

Kellam, S.J., Cannell, R.J.P., Owsianka, A.M., and Walker, J.M. 1988. Results of large-scale screening programme to detect antifungal activity from marine and fresh water microalgae in laboratory culture. Brit. Phycol J. 23, 45-47.

Kobbia, I.A. and Zaki, D. 1976. Biological evaluation of algal filtrates. Planta Med. 30, 90-92.

Kreitlow, S., Mundt, S. and Lindequist, U. 1999. Cyanobacteria-a potential source of new biologically active substances. Journal of Biotechnology. 70, 61-63.

Malathi, T., Babu, M. R., Mounika, T., Snehalatha, D., \& Rao, B. D. (2014). Screening of cyanobacterial strains for antibacterial activity. Phykos, 44(2), 6-11.

Marrez, D. A., \& Sultan, Y. Y. (2016). Antifungal activity of the cyanobacterium Microcystis aeruginosa against mycotoxigenic fungi. Journal of Applied Pharmaceutical Science, 6(11), 191-198.

Moikeha, S.N and Chu, G.W. 1971. Dermatitis-producing alfa Lyngbya majuscula Gomont in Hawaii. II. Biological properties of the toxic factor. Journal of Phycology. 7, 813.

Mundt, S., kreitlow, S., Nowotny, A. and Effmert, U. 2001. Biological and pharmacological investigation of selected cyanobacteria. Int. J. Hyg.Environ. Health. 203, 327-334.

Ohta, S., Chang, T., Ikegami, N., Kondo, M. and Miyata, H. 1993. Antibiotic substance produced by a newly isolated marine microalga, Chlorococcum HS-101. Bull. Environ. Contam. Toxicol. 50, 171-178.

Ozdemir, G., Karabay, N.U., Dalay, M.C. and Pzarbasi, B. 2004. Antibacterial activity of volatile component and Various Extracts of Spirulina platensis. Phytother. Res. 18, 754-757.

Saurav, K., Macho, M., Kust, A., Delawská, K., Hájek, J., \& Hrouzek, P. (2019). Antimicrobial activity and bioactive profiling of heterocytous cyanobacterial strains using
MS/MS-based molecular networking. Folia microbiologica, 64(5), 645-654.

Singh, I.P., Milligan, K.E. and Gerwick, W.H. 1999. Tanikolide, a toxic and antifungal lactone from the marine Cyanobacterium Lyngbya majuscula. J. Nat. Prod. 62, 1333-1335.

Smitka, T.A., Bonjouklian, R., Doolin, L., Jones, N.D., Deeter, J.B., Yoshida, W.Y., Prinsep, M.R., Moore, R.E. and Patterson, G.M.L. 1992. Ambiguine isonitriles, fungicidal hapalindole-type alkaloids from three genera of blue-green algae belonging to the Stigonemataceae. J. Org. Chem. 57, 857-861.

Soltani, N., Khavari-Nejad, R.A., Yazdi, M.T., Shokrevi, S., Fernandez-valiente, E. 2005. Screening of Soil Cyanobacteria for Antifungal and Antibacterial Activity. Pharmaceutical Biology. 43, 455-459.

Stensvik, Skulberg, O.M., Underdal, B. and Hormazabal, V. 1998. Antibacterial properties of extracts from selected planktonic freshwater cyanobacteria-a comparative study of bacterial bioassays. The Society for Applied Microbiology. 84, 1117-1124.

Sundaramanickam, A., Palanivel, S., Shekhar, S., Kumaresan, S., \& Balasubramanian, T. (2015). In vitro evaluation of Antimicrobial activity of some selected Cyanobacterial extracts against human pathogens. IJAPBC, 4(1), 36-43.

Vanlalveni, C., Rajkumari, K., Biswas, A., Adhikari, P. P., Lalfakzuala, R., \& Rokhum, L. (2018). Green synthesis of silver nanoparticles using Nostoc linckia and its antimicrobial activity: a novel biological approach. BioNanoScience, 8(2), 624-631.

Welch, A.M. 1962. Preliminary survey of fungistatic properties of marine algae. J. Bacteriol. 83, 97-99.

Welch, A.M. 1962. Preliminary survey of fungistatic properties of marine algae. J. Bacteriol. 83, 97-99.

Wijesekara, W. A. M. A., \& Manage, P. M. (2017). In vitro screening of, antibacterial antifungal and cytotoxicity activities in crude extract of freshwater cyanobacterium Oscillatoria sp. Journal of Tropical Forestry and Environment, 7(2).

Yücer, T. D., Beyatl1, Y., \& Pabuçcu, K. (2018). The antiproliferative and antimicrobial effects of cultivated Anabaena circinalis Rabenhorts ex Bornet and Flahault and Nostoc entophytum Bornet and Flahault. Tropical Journal of Pharmaceutical Research, 17(8), 1571-1577.

\section{How to cite this article:}

Chauhan, A., Chauhan, R. Basniwal, R.K., Narwadia, S.C. (2020) Cyanobacteria: an emerging source for antibacterial, antimycobacterial and antifungal properties Science Archives, 1 (1), 35-41 DOI: http://dx.doi.org/10.47587/SA.2020.1104

This work is licensed under a Creative Commons Attribution 4.0 International License.

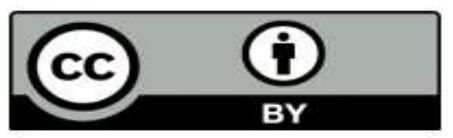

